\title{
Application of Rasch Model in Constructing Walkability Indices for Urban Neighborhood Area
}

\author{
Roslina Sapawi, Ismail Said ${ }^{1}$ \\ ${ }^{1}$ Associate Professor \\ Faculty of Built Environment, \\ Universiti Teknologi Malaysia, Skudai, Johor Malaysia \\ olynrc@yahoo.com
}

\begin{abstract}
Physical attributes for walkable urban neighborhood required summary of indices. The development of indices is based on the hierarchy of walking need theory which applies dimensions of accessibility, safety, comfort and pleasurability. The aim of this research is to construct indices of physical attributes by detecting differential item functioning (DIF) based on respondent's demographic factors and their perceived environment. 7 he ßndings using the Rasch model has dropped 16 items and maintains 20 items that reliable to gauge the 4 dimensions. This research could be used to obtain indices in a justly manner and become an indicator for walkable urban neighbourhood model.

Keywords: Walkability; urban neighbourhoods; physical environment attributes, Rasch measurement model

eISSN ISSN 2514-751X @ 2018. The Authors. Published for AMER ABRA cE-Bs by e-International Publishing House, Ltd., UK. This is an open access article under the CC BY-NC-ND license (http://creativecommons.org/licenses/by-nc-nd/4.0/). Peer-review under responsibility of AMER (Association of Malaysian Environment-Behaviour Researchers), ABRA (Association of Behavioural Researchers on Asians) and cE-Bs (Centre for Environment-Behaviour Studies), Faculty of Architecture, Planning \& Surveying, Universiti Teknologi MARA, Malaysia.

DOI: https://doi.org/10.21834/aje-bs.v3i6.234
\end{abstract}




\subsection{Introduction}

There are a vast numbers of physical attributes for walkable environment which present as antecedent within the walking decision- making process, however, it is not clearly understood which of these factors are most salient, nor is it clear how or whether these factors interact in affecting a person's level of physical activity. The dimension of environmental physical attributes remains a debate in walkability research. Satisfaction on the individual's basic needs is essential before he or she can consider higher-order needs. There is a need to use more stringent methodologies to develop valid and reliable indices of physical attributes. It is useful for assessing people needs on walkable environment before testing them in the real models of physical activity. In order to construct indices, a pre tested evaluation need to be done to see how compatible it is in further detail research. As refer to hierarchy of walking needs framework by (Mariela, 2005), there are five dimension level of need which considered within the walking decision making process; which are feasibility, accessibility, safety, comfort and pleasurability. Regard to environmental influences and psychometric properties, the dimension level of need might be differing from one area to another.

Therefore, the aim for this research is to build indices upon research undertaken by Mariela and colleagues by examining how environmental attributes interrelated with walking activity in urban neighbourhood area through people agreement. The Rasch model has used to examine both validity and reliability of the attributes listed. This model facilitated in measuring person reliability and attribute reliability which allows item elimination based on tvalue and differential measure. This paper reveals from the pilot study finding on the establishment of environmental attributes required by the researcher in acquiring significant indices of walkable environment

\subsection{Methodology}

A pilot study was carried out and conducted at Bandar Baru Uda, one of the urban neighbourhood in Johor Bahru city centre. Bandar Baru Uda's mosque was selected as the central point for walkable catchment area asit is surrounded with mixed land uses such as residential, high school, religious school, community hall and commercial areas which direct and indirectly encourage walking activity. The survey used criterion reference questionnaire which consisted of 45 questions each; seeking respondents' perceived and agreement on prescribed tasks. The respondents have to state their agreement, or disagreement on the listed competency physical attributes by ranked each of them according to their preference of priority on a rating scale of 1 to 5 . The responses will then be tabulated and analyse using Rasch Measurement Model with the aid of Rasch analysis software (Bond and Fox, 2007).

\section{Metadata Analysis}

The study uses the concept of hierarchy of walking needs. This concept served as the framework in developing the concept for physical attributes and focuses on the resident's acceptance on respected study area. There are five dimensions contributed to the walkable environment (Mariela, 2008); feasibility, accessibility, safety, comfort and pleasurability. 


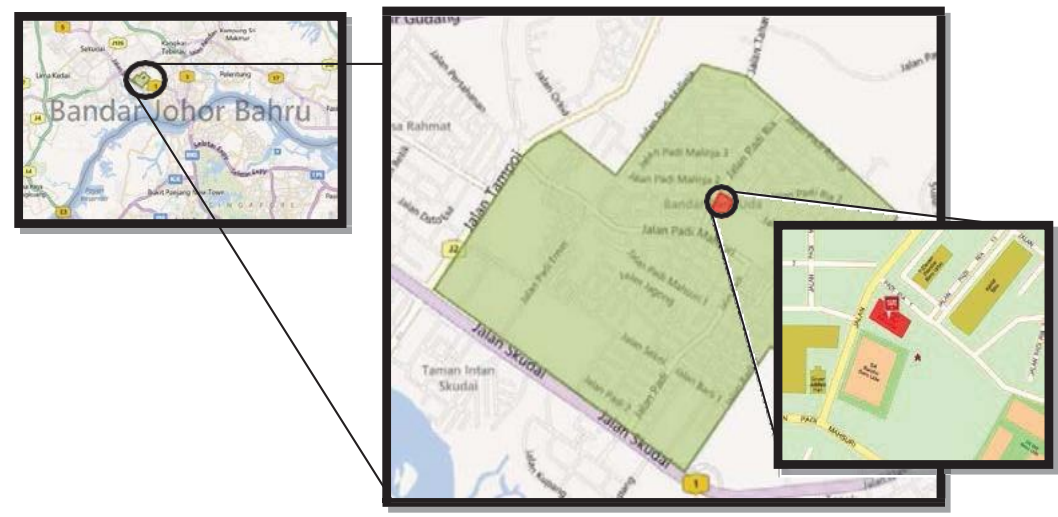

Figure 1: Location Map of Bandar Baru Uda, Johor Malaysia

Table 1: Dimensions and Label of Physical Elements

\begin{tabular}{|c|c|c|c|}
\hline Dimension & Sub Dimension & Items & Item label \\
\hline \multirow[t]{8}{*}{ Accessibility } & Access to service & Pattern of street network & A1 \\
\hline & & $\begin{array}{l}\text { Variety and proximity of } \\
\text { activities }\end{array}$ & A2 \\
\hline & & $\begin{array}{l}\text { Connectivity between } \\
\text { uses }\end{array}$ & A3 \\
\hline & & Mix land use & A4 \\
\hline & & Physical barrier & A5 \\
\hline & & $\begin{array}{l}\text { Walking related } \\
\text { infrastructure }\end{array}$ & $A B$ \\
\hline & & Distance to destination & A7 \\
\hline & & $\begin{array}{l}\text { Clustered development } \\
\text { pattem }\end{array}$ & A8 \\
\hline \multirow[t]{12}{*}{ Safety } & Safety from crime & Undesirable land use & S1 \\
\hline & & Graffiti & $\$ 2$ \\
\hline & & Vacant building & S3 \\
\hline & & Abandon building & $\$ 4$ \\
\hline & & Street lighting & S5 \\
\hline & & People present & S6 \\
\hline & & Natural surveillance & S7 \\
\hline & & Presence of back lane & S8 \\
\hline & Safety from vehicles & Street access control & Se \\
\hline & & Street barriers & $\$ 10$ \\
\hline & & Crossing facilities & S11 \\
\hline & & Traffic volume and speed & $\$ 12$ \\
\hline \multirow[t]{4}{*}{ Comfort } & Places for walking & Sidewalk buffer & $\mathrm{Cl}$ \\
\hline & & Street width & $\mathrm{C} 2$ \\
\hline & & Block length & $\mathrm{C} 3$ \\
\hline & & Sidewalk width & $\mathrm{C4}$ \\
\hline
\end{tabular}




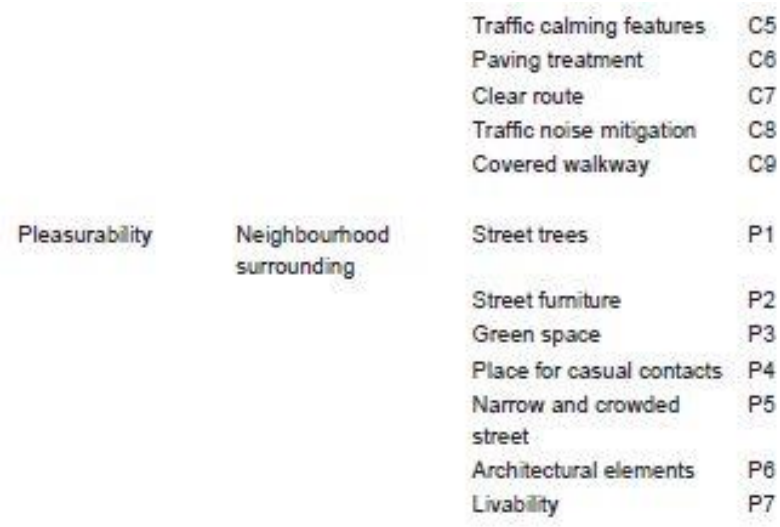

Feasibility related to individuals or group level of circumstances (Dieleman, 2002; Ball, 2000; Booth, 1997). In this research, subgroups feasibility dimension deliberate as independent variables, whilst, physicalattributes categorized in accessibility, safety, comfort and pleasurability dimension deliberate as dependent variables. These attributes tabulated in Table 1. Afterward, attributes identification within each of respective dimension will be the basis of the questionnaire constructs (Azrilah, 2008, Linacre, 2008).

\subsection{Results and Discussions}

This study was designed to provide answers to two questions; (1) Does the attributes listed valid and reliable to be used as walking indices particularly in Bandar Baru Uda, Johor, Malaysia? (2) Does the attributes perceived differently according to different groups of gender, age, educational background and health condition?. Table 2 shows the responses from feasibility dimension on each subgroup.

Table 2: Profile of Respondent

\begin{tabular}{llllll}
\hline Subgroups & N & Factors (group) & & Frequency & Percentage \\
\hline Gender & 26 & Male & 1 & 11 & 42.3 \\
& & Female & 2 & 15 & 57.7 \\
Age & 26 & $13-18$ & 1 & 4 & 15.4 \\
& & $19-40$ & 2 & 8 & 30.8 \\
\multirow{5}{*}{ Educational Background } & \multirow{2}{*}{26} & $41-65$ & 3 & 14 & 53.8 \\
& PMR/SRP & 1 & 5 & 19.3 \\
& & SPM & 2 & 8 & 30.8 \\
& STPM & 3 & 1 & 3.8 \\
& & Diploma & 4 & 8 & 30.8 \\
\multirow{4}{*}{ Health condition } & Degree & 5 & 2 & 7.7 \\
& & Postgraduate & 6 & 1 & 3.8 \\
& \multirow{2}{*}{26} & Professional & 7 & 1 & 3.8 \\
& & Health Problem & 1 & 8 & 30.8 \\
& & No health Problem & 2 & 18 & 69.2 \\
\hline
\end{tabular}


Measuring construct validity, is by looking at pointmeasure correlation (PTMEA Corr) value; whereby positive unidimensional items value means that the items are working together to measure a single underlying construct (Bond and Fox, 2007). In this research, all items show positive value with index $>0.20$. Therefore, all 36 physical attributes in the questionnaire are measuring 4 walkability dimensions. This analysis is the basic step to gauge the validity construct used to build and validate the physical attributes indices. PTMEA Corr value will increase if misfit items are dropped from cluster item measurement.

Figure 2 shows the number of respondents and the difficulty of items capability hierarchy above a logit scale.

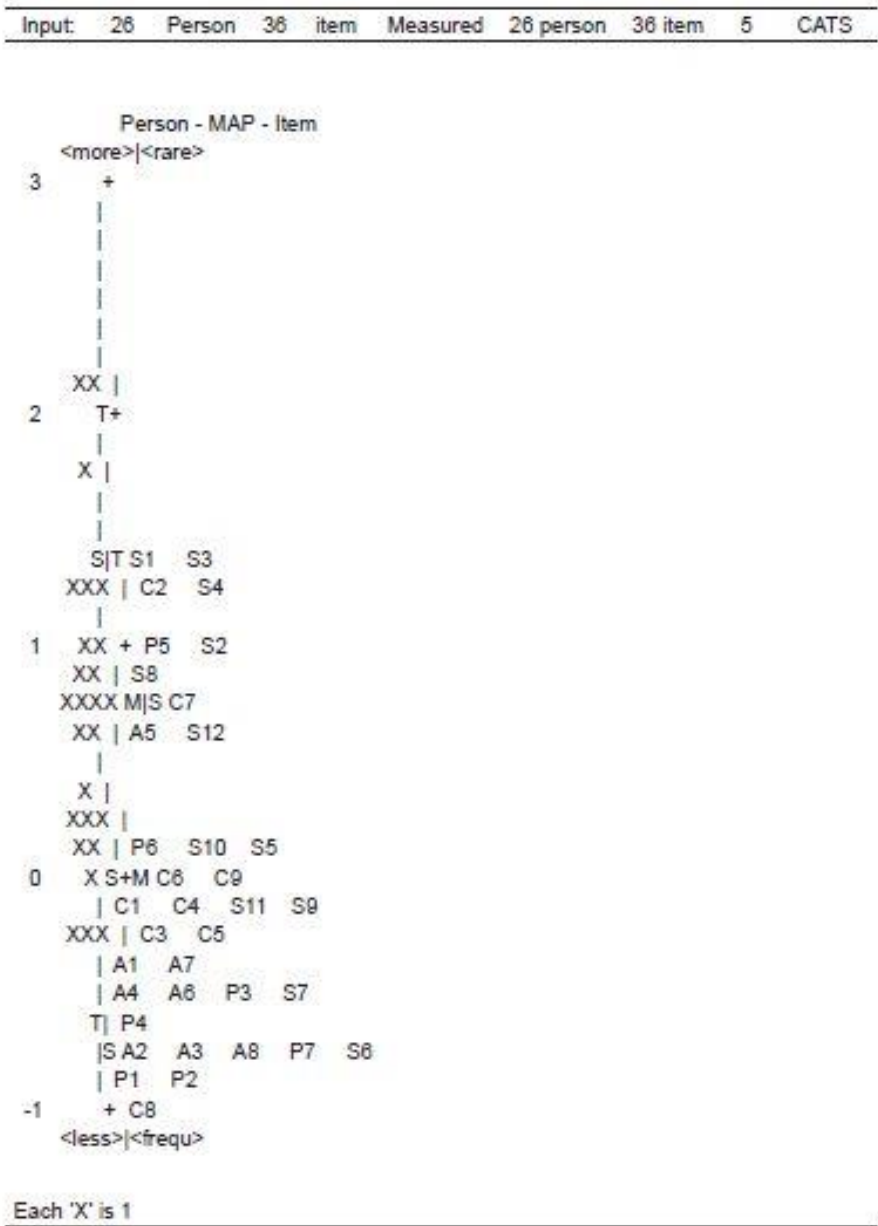

Figure 2: Person-map Item of Physical Attributes Indices 
The results have confirmed that all item is scattered and pointing towards the capability level of respondents' diversity. The ranking of respondents with high capability (easily to agree) is above the scale, whilst the ranking of lower respondents (difficult to agree) is below the scale. Person-map item has clearly shown item S3 (vacant building) is the hardest to be agree. This reflects respondent awareness towards their environment. It is found no vacant building surrounded the mosque; thus it might be hard for the respondent to agree on vacant building effect towards their walking activity as they are not experienced it. Meanwhile item C8 (traffic noice mitigation) is the easiest to be agreed. This physical attributes become the most salient among other attributes. The location and geographical factors of the mosque which surrounded with various kind of land uses, occurrence of traffic noise can be a major issue. Regardless of its location, traffic noise mitigation is deem needed by the respondent in order to give them peacefulness feeling on their way to the mosque and sacred feeling when stay inside it. As refer to Linacre (2008), the difficult items could be answered by respondents with high capability, whilst easy item could be answered with high and low ability. Overlapping items measure different elements with different levels of difficulty (Bond and Fox, 2007).

Table 3 shows the item fit index (infit/ outfit MNSQ) of 36 items in physical attributes indices. Bond and Fox (2007) explain that the acceptable range is between 0.6 to 1.4 logit. Higher value of 1.4 logit and shows items that is not homogenous with other items within one measurement scale. Item with value less than 0.6 logit shows overlapping items with other items. Items which need further verification or suggested being dropped are item S12, S5, P1, $\mathrm{P} 2$, P4 and A1.

Table 3: Item Statistic Misfit Order

\begin{tabular}{|c|c|c|c|c|c|c|c|c|c|}
\hline \multirow{2}{*}{$\begin{array}{l}\text { ENTRY } \\
\text { NUMBER }\end{array}$} & \multirow{2}{*}{$\begin{array}{l}\text { RAW } \\
\text { SCORE }\end{array}$} & \multirow{2}{*}{ COUNT } & \multirow{2}{*}{ MEASURE } & \multicolumn{2}{|c|}{ INFIT } & \multicolumn{2}{|c|}{ OUTFIT } & \multirow{2}{*}{$\begin{array}{l}\text { PTMEA } \\
\text { CORR. }\end{array}$} & \multirow{2}{*}{ ITEM } \\
\hline & & & & MNSQ & ZSTD & MNSQ & ZSTD & & \\
\hline 20 & 83 & 28 & 0.81 & 1.74 & 2.8 & 1.60 & 2.3 & 0.33 & S12 \\
\hline 13 & 85 & 26 & -0.8 & 1.88 & 2.1 & 1.65 & 2.0 & 0.26 & S5 \\
\hline 30 & 110 & 28 & -0.84 & 1.83 & 1.7 & 1.67 & 1.8 & 0.23 & P1 \\
\hline 31 & 110 & 26 & -0.84 & 1.12 & 0.5 & 1.48 & 1.4 & 0.22 & P2 \\
\hline 33 & 107 & 28 & -0.62 & 0.57 & -1.4 & 0.57 & -1.5 & 0.40 & P4 \\
\hline 1 & 103 & 28 & -0.35 & 0.52 & -1.8 & 0.5 & -1.8 & 0.54 & A1 \\
\hline
\end{tabular}

Further analysis has carried out to study the existence of Gender Differential Item Functioning (GDIF) among the physical attributes indices construct. To analysed GDIF, Winstep performs two tailed t-test to investigate the significant difference between two index difficulties. The critical value rests with value 2.0 for all DIF analysis. In addition, GDIF Contrast index has used to show the difference of gap confirmation level for each item between males and females. Value of 0.5 logit DIF contrast would be vital for Likert scale (Lai Eton, 2002). A negative index of GDIF contrast shows that the item is easy to be agreed by males. Conversely, positive index show the item is easy to be confirmed by female respondent. DIF measurement is the difficulty index of this item for this group, with other elements held constant.

Table 4 displays results of GDIF analysis and C2 appear to be bias between male and female. Only 1 item (C2 - street width) out of 26 items shows significant GDIF. Male was found 
out to be easier to agree with this item compared than female. Street width item was looking at howthe width of the street affects people walking activity. Metro (2002) claimed that, the wider the street, the difficult for people to walk as the wide street lead to high vehicle speed. Male was observed to perceive easier to walk and cross the street as they are more aware on the threat. For instance, they prefer not to use the road crossing to cross the road. However, female was perceived differently. They were observed to be more careful on making selection on which way to use for walking or crossing the road.

Table 4: Gender differential Item Functional Analysis

\begin{tabular}{ccccccc}
\hline $\begin{array}{c}\text { Group } \\
\text { (Male) }\end{array}$ & $\begin{array}{c}\text { DIF measure } \\
\text { (Difficulty } \\
\text { measure) }\end{array}$ & $\begin{array}{c}\text { Group } \\
\text { (Female) }\end{array}$ & $\begin{array}{c}\text { DIF measure } \\
\text { (Difficulty } \\
\text { measure) }\end{array}$ & $\begin{array}{c}\text { GDIF Contrast } \\
\text { (DIF size) }\end{array}$ & t-value & Item label \\
\hline 1 & 1.08 & 2 & 2.39 & 1.79 & 2.72 & $\mathrm{C} 2$ \\
\hline
\end{tabular}

Table 5 displays result of DIF analysis based on age. There are 8 items detected with age DIF. Group 1 (13 - 18 years old) commonly shows significant DIF on their perceptions as compared to other groups. Thus, to get precise result on walking activity in neighbourhood area; its suggested dropping this group depend on the scope of the study. There are also 8 items detected with educational background DIF as refer to Table6. Item A5 (physical barrier), C2 (street width), and P5 (Narrow and crowded street) show serious DIF with more than 3 cross sectional DIF between the groups. These items suggested being dropped. Meanwhile, S4 (Abandon building) show DIF between respondent with inadequate health condition and good health condition as refer to Table 7 . Although this research has reflected 6 misfit items, only 2 items have DIF significant, which are item S12 (traffic volume and control) on education background DIF and P1 (street trees) on age DIF.

Table 5: Differential Item Functioning Based on Age

\begin{tabular}{|c|c|c|c|c|c|c|}
\hline $\begin{array}{c}\text { Group } \\
\text { (years) } \\
1(13-18) \\
2(19-40) \\
3(41-65)\end{array}$ & $\begin{array}{l}\text { DIF measure } \\
\text { (Difficulty } \\
\text { measure) }\end{array}$ & $\begin{array}{c}\text { Group (years) } \\
1(13-18) \\
2(19-40) \\
3(41-65)\end{array}$ & $\begin{array}{c}\text { DIF } \\
\text { measure } \\
\text { (Difficulty } \\
\text { measure) }\end{array}$ & $\begin{array}{c}\text { DIF Contrast } \\
\text { (Dif size) }\end{array}$ & $\begin{array}{c}\mathrm{t}- \\
\text { value }\end{array}$ & Item \\
\hline 1 & 2.71 & 3 & 1.10 & 1.61 & 2.1 & A5 \\
\hline 1 & 0.74 & 2 & -0.24 & 1.68 & 2.35 & $5 \theta$ \\
\hline 1 & 2.02 & 2 & 0.3 & 1.73 & 2.34 & $\$ 10$ \\
\hline 1 & 2.02 & 3 & 0.32 & 1.70 & 2.46 & $S 10$ \\
\hline 1 & 3.38 & 3 & 1.26 & 2.13 & 2.78 & $\mathrm{C} 2$ \\
\hline 1 & 1.04 & 3 & -0.68 & 1.72 & 2.27 & C5 \\
\hline 1 & 4.44 & 2 & 2.28 & 2.16 & 2.60 & P5 \\
\hline 1 & 4.44 & 3 & 1.82 & 2.62 & 3.39 & P5 \\
\hline 2 & 0.88 & 1 & -1.81 & 2.27 & 2.03 & P3 \\
\hline 3 & -0.24 & 1 & -12.18 & 1.24 & 2.16 & P1 \\
\hline
\end{tabular}

Table 6: Differential Item Functioning Based on Educational Background 


\begin{tabular}{ccccccc}
\hline $\begin{array}{c}\text { Group } \\
\text { (education } \\
\text { background) }\end{array}$ & $\begin{array}{c}\text { DIF } \\
\text { measure } \\
\text { (Difficulty } \\
\text { measure) }\end{array}$ & $\begin{array}{c}\text { Group } \\
\text { (education } \\
\text { background) }\end{array}$ & $\begin{array}{c}\text { DIF } \\
\text { measure } \\
\text { (Difficulty } \\
\text { measure) }\end{array}$ & $\begin{array}{c}\text { DIF Contrast } \\
\text { (Dif size) }\end{array}$ & t - value & Item \\
\hline 1 & 2.57 & 4 & 0.86 & 1.71 & 2.22 & A5 \\
1 & 2.57 & 5 & -1.37 & 3.94 & 2.61 & A5 \\
2 & 1.62 & 5 & -1.37 & 2.99 & 2.04 & A5 \\
3 & 2.94 & 5 & -1.37 & 4.31 & 2.30 & A5 \\
4 & 0.4 & 2 & -1.53 & 1.93 & 2.04 & A2 \\
6 & 2.46 & 5 & -1.37 & 3.83 & 2.22 & A5 \\
2 & 1.32 & 1 & -0.29 & 1.61 & 1.55 & S2 \\
2 & 1.32 & 3 & -1.32 & 2.64 & 2.03 & S10 \\
2 & 1.32 & 4 & 0.13 & 1.19 & 2.14 & S10 \\
3 & 2.19 & 5 & -0.84 & 3.04 & 2.28 & S12 \\
3 & 2.19 & 7 & -1.01 & 3.20 & 2.02 & S12 \\
1 & 2.68 & 7 & -1.54 & 4.22 & 2.48 & C2 \\
2 & 1.83 & 7 & -1.54 & 3.37 & 2.03 & C2 \\
3 & 3.47 & 7 & -1.54 & 5.01 & 2.49 & C2 \\
6 & 1.74 & 1 & -1.16 & 2.90 & 2.29 & C4 \\
1 & 4.11 & 2 & 1.76 & 2.35 & 3.16 & P5 \\
1 & 4.11 & 4 & 1.83 & 2.29 & 3.06 & P5 \\
1 & 4.11 & 5 & 1.69 & 2.42 & 2.07 & P5 \\
\hline
\end{tabular}

Table 7: Differential Item Functioning Based on Health Condition

\begin{tabular}{ccccccc}
\hline $\begin{array}{c}\text { Group } \\
\text { (with health } \\
\text { problem) }\end{array}$ & $\begin{array}{c}\text { DIF } \\
\text { measure } \\
\text { (Difficulty } \\
\text { measure) }\end{array}$ & $\begin{array}{c}\text { Group } \\
\text { (without } \\
\text { health } \\
\text { problem) }\end{array}$ & $\begin{array}{c}\text { DIF } \\
\text { measure } \\
\text { (Difficulty } \\
\text { measure) }\end{array}$ & $\begin{array}{c}\text { DIF contrast } \\
\text { (DIF size) }\end{array}$ & t value & item \\
\hline 2 & 1.27 & 1 & 0.07 & 1.19 & 2.57 & $\mathrm{S4}$ \\
\hline
\end{tabular}

To summarize, there are 16 items or $38.9 \%$ (2 misfit items together with DIF item, 4 misfit items and 10 DIF item) that need to be dropped in the research. Such action would enhance the reliability and validity of constructing indices for physical attributes that support walking in urban neighbourhood area. The study is parallel to studies by Mariela (2005) which state that different perception and agreement of respondent on their GDIF and DIF carried out on physical attributes indices for walking is an effort to ensure evaluation exercise is fair for the respondent who undergoes it (Dodeen, 2004).

\subsection{Conclusion}

Identification on physical environmental indices in urban neighbourhood area is essential in order to develop walkable environment. Since the neighbourhood residents were from diverse background, constructing the indices need to be carried out justly. Therefore, DIF inspection in Rasch measurement model classifies items based on gender, age, educational background 
and health condition. Separation or exclusion of items that which identified by DIF would increase the reliability and validity of the indices. In order to build a walkability model for urban neighbourhood area, it's suggested to consider physical environmental indices that are free from DIF. This research is only a pilot study with the minimum number of respondents. The research was purposely to understand the interrelation between resident and their perceived on physical attributes within Malaysian context particularly in Bandar Baru Uda, Johor. Thus, larger scales of respondents which include wider sample on different types of the neighboorhood are advisable as to get better precise result. This would enrich the diverse feasibility dimension of the respondents and the research tool.

\section{References}

Azrilah A.A, Azlinah, M., Azami, Z., Sohaimi, Z, Hamzah A.G., Mohd Saidfudin, M. (2008), Determinationoffacevalidity test for information irofessionals competency attributes using Rasch analysis" International Journal Education and Information Technologies.

Ball, K., Crawford, D., \& Owen, N. (2000). Too fat to exercise? Obesity as a barrier to physical activity. Australian and New Zealand Journal of Public Health, 24, 331-333.

Bond T. G. and Fox C. M, (2007) Applying the rasch model: fundamental measurement in the Human Sciences, $2^{\text {nd }}$ ed. Mahwah, New Jersey: Lawrence Erlbaum.

Booth, M., Bauman, A., Owen, N., \& Gore, C. (1997). Physical activity preferences, preferred sources of assistance, and perceived barriers to increased activity among physically inactive Australians. Preventive Medicine, 26, 131137.

Dieleman, F., Dijst, M., \& Burghouwt, G. (2002). Urban form and travel behavior: Micro-level household attributes and residential context. Urban Studies, 39, 507-528.

Dooden, H. (2004). Stability of differential item functioning over a single population in survey data. The Journal of Experimental72(3):181-194.

Lai, J. S., Eton, D. T. (2002), Clinically meaningful gaps. Rasch MeasurementTransactions 15(4):850

Linacre J. M. (2008) Development and validation of instrument, Rasch measurement transaction, Vol. 21.

Mariela A. (2005). To Walk or Not to Walk? The Hierarchy of Walking Needs, Journal of Environment and Behavior, $37 ; 808$.

Mariela A., Marlon G. B., Kristen D., Tracy M., and Craig L. A., (2008) The Relationship of Neighborhood Built Environment Features and Adult Parents' Walking, Journal of Urban Design, Vol. 13:pp 29-51

Metro (2002) Creating Livable Street; Street Design Guidelines for 2040 p.15. 